\title{
Education of Value in Multicultural Based Social Science Learning in Basic Schools in Efforts to Implementation of Character Education
}

\author{
Ine Kusuma Aryani ${ }^{1}$, Ristiana Dyah Purwandari ${ }^{2}$, Beny Wijarnako Kertopati ${ }^{3}$ \\ \{ inepascapendas@gmail.com $\}$ \\ ${ }^{1,2,3}$ Universitas Muhammadiyah Purwokerto
}

\begin{abstract}
If education is power, then Value Education is a source of power or strength, one of the most important aspects of learning Social Sciences (IPS) Multicultural basic, which is a comprehensive, holistic, continuous and educational world content. In the sense of value education that underlies character education in social studies subjects, using strategies to implement an understanding of character education until finally implementing value education that truly develops the character of elementary school students.
\end{abstract}

Keywords: Value Education, Character Education, Multicultural-Based Social Studies, Basic Education

\section{Introduction}

Character education is a hot topic to be discussed, and also a hot topic to be discussed by the general public, both directly by the community, as well as articles, research and discourse analysis. The point is that character education will never be separated from aspects of culture, values, morals/ethics/morals, norms (religion, law, decency and decency) and the socio-cultural life of the nation. However, conditions in the field are currently starting to fade along with the increasingly sophisticated current technology of the new society 4.0 era and even now entering the new society 5.0 era, but the filter is still weak against the various cultures that enter the younger generation which is a challenge that must be faced.

There are still many more problems that arise related to character education, such as for example moral decadence or the decline in moral values carried out by students, promoting the culture of cheating, bullying cases, free sex among students, photos and videos of their own genitals, and the system. education in schools that still do not pay attention to the quality of their students. Thus, it is necessary to form human resources who have high competence from an early age by instilling character education, one of which is through multicultural elementary-based Social Science (IPS) learning.

Character education is a deliberate effort to develop good character based on core policies that are objective for both individuals and society. The character education process is based in totality on the abilities or potentials possessed by each individual including cognitive, affective and psychomotor as well as sociocultural totality functions in the context of interactions within the family, educational unit and society. [1]

There are eleven (11) principles of character education, namely: (1). Schools must be committed to core ethical values; (2). Character must be understood in its entirety, including knowledge or thoughts, feelings, and actions; (3). Schools must be proactive and act 
systematically in character learning and not just waiting for opportunities to come; (4). Schools must build an atmosphere of mutual concern for each other and become a small world (microcosm) of a caring society; (5). Opportunities to practice moral action should be varied and available to all; (6). academic study should be the main thing; (7). Schools need to develop ways to increase students' intrinsic motivation that includes core values; (8). Schools need to work together and dialogue norms regarding character education; (9). Teachers and students must share in the moral leadership of the school; (10). Parents and society must be partners in character education in schools; (11). it is necessary to evaluate the effectiveness of character education in schools, especially for teachers and employees as well as students. [1]

Value is something that is valuable, useful, necessary, expensive, which is useful for a life, especially social life. The values of social life are things that are useful in a social life. Social value is a collection of attitudes, feelings, or assumptions about something that is good, bad, right, wrong and so on. C. Kluckhon argues that all cultural values are basically five, namely the value of the nature of human life, the value of the nature of human work, the value of the nature and position of humans in space and time, the value of human relations with each other. [2]

Culture is a whole system of thinking, values, morals, norms and beliefs (belief) of humans produced by society. This system is the result of human interaction with each other and their natural environment. Systems of thinking, values, morals, norms and beliefs are used in human life and produce social systems, economic systems, belief systems, knowledge systems, technology, art and so on. Humans as social beings become producers of systems of thinking, values, morals, norms, and beliefs. However, in interactions with fellow humans and the nature of human life, it is regulated by the system of thinking, values, morals, norms, and beliefs that have been produced. When human life continues to develop, what is actually developing is the social system, economic system, belief system, science, technology and art. If it is associated with education, education is a planned effort in developing the potential of students, so that they have a system of thinking, values, morals, and beliefs that are inherited by the community and develop that legacy in a direction that is appropriate for present and future life.

Moral comes from Latin. The singular form of "moral" is mos, while the plural form is mores, each of which has the same meaning, namely custom, custom. So that it can be defined that morals are the values and norms that become a guide for a person or a group in regulating their behavior. With regard to character education that is applied from an early age, morals have a very close relationship with Kohlberg's theory of moral development. [3]

Moral/ethical/akhlaq values in Indonesia have begun to fade in recent times, this is a mistake in the historical-structural dimension. Morals are closely related to ethics and values. Ethics in the application of character education can be manifested in the process of exploring social science, respecting the potential of students, and developing, utilizing and applying science and technology in the realm of education.

Culture, morals, and values are a unified whole, which forms individual character, in this case students.

Character education of students has been embodied in the way educators speak, behave. Habits, and expectations of potential learners. Thus, it is necessary to know in advance what the character is and how to understand the character of the students.

Character is an inner determination that is developed consciously, which is ingrained in a person, which becomes his energy in daily actions to achieve the goals of high moral values. [4], character is a belief in something that cannot be ascertained whether the truth or the truth is based on perception of the local community. In addition, character can also be 
defined as a person's character, moral character, or personality which is formed from the internalization of various virtues that are believed and used as a basis for perspective, think, behave, and be trusted. Virtue consists of a number of values, morals, and norms, such as honesty, courage to act, trustworthiness, and respect for others. The interaction of a person with others fosters the character of society and the character of the nation. Thus, the development of national character can only be done through the development of one's individual character. However, because humans live in a certain social and cultural environment, the development of a person's individual character can only be done in the social and cultural environment concerned. This means that the development of national culture and character can only be carried out in an educational process that does not release students from the social environment, community culture, and national culture.

How to apply the characters into the understanding of students, both in the relationship between students and educators (teachers), students with their peers, and fellow teachers. Understanding the social character of students, not only can be done by the students themselves, but also needs to be done by all parties. The form of implementation carried out by all parties. The form of application carried out in the application of understanding the social character of students can be carried out accompanied by learning theories. The inclusion of rewards and punishments, provision of reinforcement, and pilots.

In the news, there are often cases of bullying, sexual harassment, pornography among the younger generation is a lack of understanding of the social character of individuals, specifically students. Lack of understanding of each other's social character can lead to various kinds of problems, ranging from the smallest to quite complex problems and have an impact on the culture that exists in schools as a place for character education activities to take place. Therefore, understanding the social character of students is very necessary before actually implementing character education in schools. Because if it is not done early, then what happens is that there will be disharmony during the teaching and learning process.

Social sciences (IPS) is a translation or adaptation in Indonesian of the English term social studies as a field of science taught in schools (primary education to secondary education) in the United States, England and Australia.

Social studies was born from the desire of education experts to "equip" students so that later they will be able to deal with and deal with the unexpected so that it has a wide impact, namely the emergence of various social problems. To explain this complex life cannot be approached in a discrete way. This is one of the impetus for using an integrated approach, meaning that to deal with the complexities of life, students must integrate information from the social sciences. Thus, IPS is basically a study of humans and the world around them with the main study being about human relationships. Thus, it can be concluded that the main purpose of social studies learning is to enrich and develop the lives of students by developing abilities in their environment and training students to place them in a democratic society.

Social Studies has broad links with other fields of science, especially the social field. More specifically, the objectives of teaching social studies in schools can be grouped into four components: (a) Providing students with knowledge about human experience in social life in the past, present and future, (b) Helping students to develop skills to seek and process information, (c) Help students to develop democratic values/attitudes in social life, (d) Provide opportunities for students to take part and participate in social life. based on some of the presentations that have been given, it shows that social studies is a dynamic science, and has a very high applicative value. [5]

Multiculturalism is a belief and behavior system that recognizes and respects the presence of all diverse groups in an organization or society, recognizes their different socio-cultural 
differences, and encourages and enables their continued contribution in an inclusive cultural context that empowers all in the organization or society.

Multicultural Learning is a policy in educational practice in acknowledging, accepting and affirming human differences and similarities related to gender, race, and class. [6]. Multicultural education is an attitude in looking at the uniqueness of humans without discriminating against race, culture, gender, sex, physical condition or one's economic status, especially when studied with community/social references, it will be more specific.

Multicultural education (multicultural education) is an educational strategy that utilizes the diversity of cultural backgrounds of students as one of the strengths to form a multicultural attitude. This strategy is very useful, at least for schools as educational institutions that can form a common understanding of the concept of culture, social, community. cultural differences, balance in a broad sense. [7].

Multicultural education is defined as a social policy based on the principles of cultural preservation and mutual respect among all cultural groups in society. Multicultural learning is basically a national education program so that multicultural communities can participate in realizing an ideal democratic life for their nation. [8]

In a broad context, multicultural education tries to help unite the nation in a democratic manner, by emphasizing the perspective of plurality of people in different nations, ethnicities, and cultural groups. Thus schools are conditioned to reflect the practice of democratic values. The curriculum exposes different cultural groups in society, language, and dialect, where students are better off talking about respect among themselves and upholding the values of cooperation, rather than talking about competition and prejudice between a number of students who differ in terms of race, ethnic, cultural and social status groups.

Multicultural-based learning is based on philosophical ideas about freedom, justice, equality and the protection of human rights. The nature of multicultural education prepares all students to work actively towards a common structure in school organizations and institutions. Multicultural education is not a policy that leads to the institutionalization of inclusive education and teaching and teaching by pluralism propaganda through a curriculum that plays a role in individual cultural competition.

Multicultural-based learning seeks to empower students to develop a sense of respect for people of different cultures, providing opportunities to work directly with people or groups of people of different ethnicities or races. Multicultural education also helps students to recognize the correctness of diverse cultural views, assists students in developing pride in their cultural heritage, makes students aware that value conflicts are often the cause of conflict between community groups. [9].

Multicultural education is held in an effort to develop students' abilities to view life from various cultural perspectives that are different from their own, and to be positive about cultural, racial and ethnic differences. [9].

The objectives of multicultural-based education can be identified:

1. To function the role of schools in viewing the existence of diverse students.

2.To help students in building positive treatment of cultural, racial, ethnic, and religious differences.

3.To give students resilience by teaching them their decision-making and social skills.

4.To assist students in building cross-cultural interdependence and give them a positive picture of group differences.[10]

In addition, multicultural-based learning is built on the concept of education for freedom, which aims to: 
1. Helping students or students develop knowledge, attitudes and skills to participate in democracy and community freedom.

2. Promote freedom, skills, skills across ethnic and cultural boundaries to participate in other groups and cultures. [10]

Reasons for the Need for Multicultural-Based Learning

Rationally about the importance of multicultural education, because this educational strategy is seen as having virtues, especially in:

1.Provide new learning breakthroughs that are able to increase empathy and reduce student prejudice so as to create human beings (intercultural citizens who are able to resolve conflicts nonviolently);

2. Applying potential learning approaches and strategies in promoting the process of social interaction and having a strong affective content.

3. The multicultural learning model helps teachers in managing the learning process to be more efficient and effective, especially providing the ability of students to build collaboratively and have high value commitments in the life of a pluralistic society.

4. Contribute to the Indonesian nation in resolving and managing conflicts with racial nuances that arise in society by increasing empathy and reducing prejudice.

The condition of the diversity of society and culture, positively illustrates the rich potential of a pluralist-type society, but negatively people feel uncomfortable because they do not know each other's culture. Every ethnic or race tends to have an ethnocentric spirit and ideology, which states that their group is superior to other ethnic or racial groups. the occurrence of not knowing each other's cultural identities, can encourage increased prejudice against others, in the form of antipathy based on generalization errors that are expressed as feelings. Prejudice is also directed when a group as a whole, or towards a person simply because it is a member of a particular group. Thus, prejudice has the potential to scapegoat others through stereotypes, discrimination and the creation of social distance. [11]

Implementation of character education is developed learning experiences and learning processes that lead to the formation of character in students as a whole. This process is carried out through a process of empowerment and cultivating as outlined as one of the principles of implementing national education. This process takes place in the three pillars of education, namely in the education unit, family, and community. Especially in the education unit, it can be said that the school community which consists of the School Head, teachers, administrative staff, and students with social interactions has a very clear goal, namely learning. Therefore, the school community can be said to be a learning community with certain levels, the learning process never stops, activities are carried out in a planned manner, there is a curriculum, classes, teachers, students, facilities and infrastructure, as well as school regulations, arrangements and norms that must be followed. .

In the implementation of character education, strategies are needed to deal with problems, including: (1). Strengthening Character Education in students through the curriculum used; (2). Strengthening the character education of students through the school's vision and mission; (3). Embeds explicitly embedded character values; (4). Creating a comfortable and fun environment, (5) Train teachers (teacher educators) to be more competent and have character.

The implementation of character education can of course also have an impact on the psychology of students, one of which is the formation of individual characters and individual characters as well as social characters, in which there are seeds of aggressive behavior and concern for ethics and values. 
Character can be interpreted as a person's character, character, morals, or personality which is formed from the internalization of various virtues that are believed and used as a basis for perspective, think, behave, and act, so that character is often used as a substitute for personality. Individual character is a character that appears as a form of image that is expected by the people around the individual. Character is never ending process, the sentence actually wants to describe how individual characters can continue to develop along with increasing experience and ability to solve life's problems. Basically, character is the core of development, development as a human being. Nurrachman (2010) explains that in line with the notion of character associated with social life which is understood as a stable dynamic integration between self-character and the various social roles it carries. [12]

Various kinds of social characters are said that every society that has been created by humans, whether it is feudalism, capitalism, fascism, socialism, and communism, all show human efforts to solve basic human contradictions. The contradiction in question is that a person is part but at the same time separate from nature, is part but at the same time from nature, is both an animal and a human being. As animals, people have self-awareness, mind and imagination. Typical human experiences include feelings of tenderness, love, compassion, attitudes of concern, responsibility, identity, integrity, openness, transcendence, and freedom, Fromm's values and norms.

Then Erich Fromm's theory of the character of society recognizes the assumption of cultural transmission in terms of forming a typical personality or collective personality. However, Fromm tries to explain also the socio-historical functions of the personality type that connect the typical culture of an objective culture faced by a society. To formulate this relationship effectively, a society needs to translate it into the characteristics of its individual members so that they are willing to do what must be done.

Fromm divides the structural system of society into 3 parts based on its social character: (1). System A is life-loving societies, the social character of this society is full of ideals, maintaining the continuity and development of life in all its forms., in a society system like this, destructiveness and cruelty when it rarely occurs, no destructive corporal punishment is found. Efforts to cooperate in the social structure of society like this are often found. (2). System B, namely non-destructive-aggressive society. This society has a basic element of nondestructiveness, although it is not the main thing, this society views aggressiveness and destructiveness as normal. Competition, hierarchies are common. This society has tenderness and mutual trust. (3). System C, namely destructive society. His social character is destructive, aggressive, brutal, vengeful, treacherous and full of hostility. Usually in a society like this, competition often occurs, prioritizing wealth, which if in material form is in the form of emphasizing symbols. [13]

Based on the theory that has been put forward by Fromm, [14], criticized that according to him Fromm did not clearly distinguish individual characters from social characters. Concretely, social character is a difficult concept to explain, because it covers various aspects, such as aspects of psychology, sociology, anthropology, and economics. All these aspects are interrelated and affect social life in society. So, based on this explanation, it can be concluded that basically the impact of implementing character education in influencing individual psychological conditions is complex. Why is that? This is because all aspects are complexly related to character building and the process of implementing character-based education. [15]

The appearance of characters in a place or area cannot all be directly accepted with grace by a certain social group. It is not uncommon for conflicts to arise due to the appearance of a character. For example, the character of a corruptor. This character always causes 
conflicts in various regions, especially in government areas, be it regional, national, or international scope. The emergence of this conflict can also lead to the formation of characters which will have positive or negative values. The positive value of individual character and social character can be used as a benchmark for the success rate of implementing character education in a place, in this case is a school.

\section{Method}

The research used is descriptive qualitative, meaning that the research results are analyzed in the form of a detailed description of a phenomenon. According to Bogdan and Biklen (1922) qualitative design has the following characteristics: natural setting, descriptive, prioritizing process over results, inductive data analysis, meaning is the main concern. This research was chosen because it is in accordance with the characteristics of qualitative research, is very suitable and provides opportunities in an effort to provide a qualitative understanding and explanation of a phenomenon in depth and holistically. [16]

\section{Results And Discussion}

Multicultural-Based Social Studies Curriculum in Elementary School, as follows. Social Science is a subject that comes from the social life of the community that has been selected using social science concepts that are used for learning purposes. The social life of the community is always changing from time to time. These changes can be seen in both the spatial context and the time context. Various changes that occur in people's lives must be captured by educational institutions which then become a source of learning material, this source of learning material can be formally stated in the form of a curriculum.

The social studies curriculum to be developed should have a clear philosophical foundation. The philosophical basis used refers to the real conditions of phenomena that occur in society which are constantly changing. These changes are caused by many things, one of which is the existence of social interaction between individuals or groups. Because changes in social life in society are changing, the social studies curriculum also undergoes reforms that are adapted to the integrated curriculum which is the philosophy of the social studies curriculum.

Various kinds of changes that exist in society, which also affect the perceptions and attitudes of students, it is better if the social studies curriculum is prepared based on PANCASILA which reflects the character of the nation. Thus, the main competencies that must be mastered by students are students who can develop an attitude of mutual respect and respect for each other. The development of moral, ethics, and values becomes a special reference that can support the implementation of character education in social studies learning. For example, the SD IPS curriculum which is the result of the implementation of character education is that SD IPS education must pay attention to children aged 6-12 years. Children in the group 7-11 years according to Piaget (1983). [17] is in the development of cognitive abilities at the concrete operational level. They view the world as a whole, and think that the coming year is a distant time, and that what they care about is the present and not the future that they cannot yet understand or perceive as abstract. Concepts such as time, continuous change, cardinal directions, environment, rituals, acculturation, power, democracy, values, roles, demands, or scarcity are abstract concepts that exist in the curriculum that must be taught to students.

Social studies education is one of the efforts that will bring awareness to space, time, and the surrounding environment for children. [18]. thus, the task of an educator is to develop 
an academic culture which is expected to later shape the character of students through social studies learning, including: Application of multicultural education development strategies, [19] a series of strategies as follows: (1) Integration of all cultural groups. Educators must ensure that all cultural groups, both majority and minority, in Indonesia have a proportional place in the multicultural education process; (2). Cultural balance. The study of minority groups should be carried out through an approach that is able to respect these groups as an integral part of a society; (3) Cultural festivals. In multicultural education it is possible to present cultural festivals (art, food and fashion festivals) which aim to develop in students the introduction of tolerance to other cultural characteristics; (4) Character selection. In the process of multicultural education, the presence of figures in local, national, and international events should show a balanced representation of the entire cultural group; (5) Inclusion of students' cultural values. In order for the effectiveness of achieving the goals of multicultural education to be achieved, educators must also understand and include their culture in the educational process.

Based on the development strategy in the previous paragraph, the form of its application to elementary school students, such as the commemoration of Kartini Day using traditional clothes, the August 17th Celebration with various competitions activities with traditional games: such as sack racing, climbing areca nut, etc., conveying the moral value of the song. -folk songs, children's songs and with folk tales. [20]

To realize the implementation of character education in social studies learning based on multiculturalism, it can be carried out jointly between educators and students, making activities that aim to make the material in social studies learning easier to understand, with various forms of activities as described above.

The application of character education in the classroom can be described in activities such as singing together, then describing the moral values of the song. such as a song of gratitude, mother's love, then explain what meaning can be taken from the song to students. Communicating with students by asking questions about the meaning of the song, then giving rewards to those who have dared to express their opinions.

The preparation of a multicultural elementary school-based social studies curriculum must not only pay attention to the form or characteristics of social studies subjects and include character education in it, it must also be adjusted to the cognitive development stage of students. So it is hoped that the preparation of this curriculum can be appropriate and provide maximum results in the multicultural elementary school-based social studies learning process.

\section{Conclusion}

An understanding of students' social character education is needed in realizing the successful implementation of character education in schools. Because culture, morals and values of social life are a unit that forms character and becomes the expected psychomotor. Some strategies and implementation of character education that can be applied include strengthening character education of students through the curriculum used, strengthening character education of students through the school's vision and mission, instilling character values that are explicitly implanted, creating a comfortable and pleasant environment and training educators to be more competent and character. The implementation of character education has a psychological impact in the form of character development and personality or character of students through increasing experience. The nature of social studies is a science that can explain complex life, it cannot be approached in a very separate way and besides that social studies can be applied to a very broad realm. The preparation of a multicultural elementary school-based social studies curriculum with character education should pay 
attention to the competence of educators and students in providing and absorbing learning, then implementing character education into it in a balanced, consistent, continuous and comprehensive manner.

\section{References}

[1] Saptono. 2011. Dimensions of Character Education Insights, Strategies and Practical Steps. Jakarta: Essence of Erlangga Group.

[2] Kluckhohn, C. (1951). Values and Value-Orientations In The Theory of Action: An

Exploration In Definition and Classification. In T. Person \& E.A. Shils (Eds).

Toward A General Theory of Action. Cambridge: Harvard University Press.

[3] Liliweri, A.M.S. 2005. Verbal and Non Verbal Communication. Bandung PT Citra Aditya Bakti.

[4] David, Matthew, et.al. (2007). Smart and good schools. Education week, November 2007. Retrieved March 3, 2008 from:

[5] Chapin, J.R., \& Messick, R. 1992. Elementary Social Studies. Practica; guides. New York: Logma, Inc.

[6] Sleeter, C.E. \& Grants. 1988. Making Choices for Multicultural Education, Fife Approaches to Race, Class, and Gender. New York: Macmillan Publishing Company.

[7] Koentjaraningrat, (1997). Mentality Culture and Development. Jakarta: Gramedia.

[8] Banks, J.A. 1995. Multicultural Education: Historical Development, Dimensions and Practice In Review of Research in Education, vol. 19, edited by L. Darling Hammond. Washington, D.C.: American Educational Research Association.

[9] Savage \& Armstrong. 1996. Facing Values Decision: Rational Building for Teachers, New York; Teacher College, Columbia University.

[10] Barr, R.D., Barth, J.L., Shermis, S.S. (1978). The Nature of The Social Studies, Palm Spring: An ETS Publication.

[11] Jatmiko, I.W., and Mariyono, S.D. 2008. Social Sciences Proud to Be Environmentally Insightful Person for SD'MI Class I. Jakarta: Book Center, Ministry of National Education.

[12] Nurrachman, N. 2010. Social Character: Contextualization in Education. Collection of abstracts of the National Conference and Workshop of the Indonesian Association of Educational Psychology, pp. 80-87.

[13] Hermawan, E., and Endang, H. 2008. Social Science for Elementary and MI Class I. Jakarta: Book Center, Ministry of National Education.

[14] Kuhn, T. (1990). The Role of Paradigms In The Science Revolution, (translation). Bandung: Remadja Rosdakarya.

[15] Ki Hajar Dewantara. (1962), Culture - Second Part A, Jogjakarta: Taman Siswa.

[16] Bogdan R.C. and Biklen, S.K. (1992). Qualitative Research for Education : An Introduction to Theory and Methods. Boston: Allyn and Bacon.

[17] Kneller,G.F. (Ed). (1971). Foundation of Education. (Third Edition). New York: John Wiley and Sons. 
[18] Dickerson, E., and Elizabeth, L. Banks, 1993. Character Building Series 1 (Quiet Impact, Inc. 2003): p. 14

[19] Hanurawan \& Waterworth. 1997. Multicultural Perspectives In Indonesia Social Studies Education Curriculum. Journal of Educational Sciences, 4, Special Edition, 265-275.

[20] Fromm, E. 1947. Man For Himself. New York: Holt, Rinehart and Winston. 